\title{
Urban and Peri-Urban Agriculture as A Pathway to Food Security: A Review Mapping the Use of Food Sovereignty
}

\author{
Michelle Chihambakwe ${ }^{1, *}$, Paramu Mafongoya ${ }^{1}$ and Obert Jiri ${ }^{2} \mathbb{D}$ \\ 1 School of Agricultural, Earth and Environmental Sciences, University of KwaZulu-Natal, \\ Private Bag X01, Scottsville, Pietermaritzburg 3209, South Africa; Mafongoya@ukzn.ac.za \\ 2 Faculty of Agriculture, University of Zimbabwe, Harare, P.O. Box MP 167, Mount Pleasant, Zimbabwe; \\ obertjm@gmail.com \\ * Correspondence: mchihambakwe@hotmail.com
}

Received: 14 November 2018; Accepted: 18 December 2018; Published: 20 December 2018

\begin{abstract}
Renewed interest in the nexus between sustainability and food security has led to growing discussions on the use of food sovereignty principles in agricultural practice. As a result of the transfiguration of the urban and socioeconomic landscape in the global South, urban and peri-urban agriculture has been touted as a potential response to increasing food insecurity in cities. Yet, both urban and peri-urban agriculture and food sovereignty have attracted cursory scholarship and programming in Zimbabwe due to fixation on more dominant rural and conventional agriculture. Beyond the rudimentary idea that the urban landscape is unfit for food production, literature has demonstrated that urban households have ingrained urban and peri-urban agriculture into their livelihoods. Regardless, institutional arrangements governing the practice remain ambivalent towards the practice, bringing to question the ability of households to fully exploit the benefits of the practice. This review underscores that failure to involve of all stakeholders undermines urban and peri-urban agriculture, consequently leading to heightened food insecurity and use of unsustainable practices. By delving into the political economy of food, we hope to stimulate discussion centered on food sovereignty within and urban spaces and beyond.
\end{abstract}

Keywords: agroecology; climate change; food security; food sovereignty; urban and peri-urban agriculture; urban cultivators

\section{Introduction}

Urban food security is a key challenge for most households in cities. According to the Food and Agricultural Organisation (FAO) urban landscapes in sub-Saharan Africa rank highly in terms of urban poverty and undernourishment [1]. The global financial recession and ensuing increase in fuel and food prices (2007/8) have led to the mushrooming of research on food security [2]. Once defined as a rural concern, urbanisation has amplified the visibility of food insecurity in sub-Saharan African (SSA) cities. These developments have increased research interest in urban food security on the continent $[3,4]$. Sen's critique on the dominant of literature citing availability as the key problem can be credited to these developments. His critique resulted in a profound shift in some of the scholarship from a global, regional and national focus to issues of access at the local level [5]. Food access is one of the critical issues that plagues the African continent [6]. Cementing Sen's argument on the importance of entitlements, the erratic income earning opportunities in the global South have heightened home-grown production. It has been conclusively shown that urban and peri-urban agriculture (UPA) contributes to food security at varying levels [1]. The past decade has seen the emergence of urban food production 
in cities and growing scholarship on UPA $[7,8]$. Notwithstanding UPA's global coverage, literature has demonstrated its dominance in the global South because of growing food security concerns. Available evidence also seems to suggest that UPA has been practised by households for decades, yet an understanding of the practice remains limited [9].

Before delving into literature on food (in)security in the region, it is necessary to define the concept of food security. It refers to 'a situation where all people, at all times, have physical, social and economic access to sufficient, safe and nutritious food which meets their dietary needs and food preferences for an active and healthy life' [10]. As noted in literature the concurrent attainment of four vital elements (availability, access, utilisation and stability) embedded in this definition are a precondition for food security [11,12]. However, most studies on UPA fail to fully acknowledge the importance of all elements [11,13], pointing to definitional complexities. Conversely, food insecurity "[ ... ] exists whenever the availability of nutritionally adequate and safe foods or the ability to acquire acceptable foods in socially acceptable ways is limited or uncertain" [14]. Access is the most challenging element of food provisioning because even though food may be in abundance, access may prove difficult for some. Access to food involves acquisition in cash or kind. Sen's ground-breaking investigation into food provisioning challenges, revealed that factors beyond the household's food production capabilities are fundamental [5]. His assertion is grounded on the fact that the dearth in food is also a product of market failures related to irregularities in food supply.

Four decades after Sen's declaration on the importance of access, most studies on UPA remain myopic in their focus. They pay limited or no attention to the link between access, human rights and food security. For example, Kimani-Murage et al and Smart et al focus on the vulnerability of poor households to food insecurity in relation to monetary crises and their ripple-effects $[15,16]$. Kimani-Murage's mixed methods study to explore food security among informal settlers in Nairobi after the election crisis in $2007 / 8$. Their findings suggest that while food insecurity was typical among households, it was heightened by political instability [15]. Using the Household Food Insecurity Access Scale (HFIAS) the study concluded that a meagre $15 \%$ of the households were food secure. Half of the respondents were cited as experiencing chronic food insecurity [15]. Respondents had little regard for the nutritional component of the food they consumed because of poverty. Writing on the impact of the economic meltdown resulting in the closure of copper mines and allied industries in the 1980s, Smart et al demonstrate how UA provided sustenance for residents in the Copperbelt [16]. This example shows that, in times of crisis, UA is a lifeline that guarantees practising households an addition to their food supply.

Global reactions to conventional agriculture are centred on environmental concerns. A key aspect of these is that the nature of production and distribution increases greenhouse gas (GHG) emissions [17] which has detrimental effects on the macroclimate. Such concerns also stem from agriculture's susceptibility to the effects of climate change. Cementing this, Pereira highlights the disturbing trend where climate variability continues to threaten the capabilities of governments and households to produce sufficient quantities of food [18]. Food sovereignty proposes the framing agricultural practices around biotic ecologies as one of the ways to reducing the negative impacts of climate change and consequently abetting food insecurity [19]. The concept also offers a lens through which the paper explores space, agency and power dynamics as they relate to the agronomic and horticultural practices of urban cultivators. In recent years, there has been an upsurge in research into food sovereignty [20-25]. Most of these studies are however, concentrated in South and North America. While scholarship in the global South is growing, the concept is still in its embryonic stages in the African context [22].

In the first section, this paper discusses the (in)significance of UPA. Consequently, we review literature on challenges and constraints of the practice. These constraints refer to those experienced by urban cultivators, and counter arguments from municipal and environmental agencies. Beyond, merits, demerits and constraints, this review explores production practices, power dynamics and climate change, which in combination, aid in making the link between UPA and food sovereignty. 
Food sovereignty's pointed questions unpacking autonomy from production to consumption have important qualifications that have the potential to improve urban food security.

\section{2. (In)Significance of UPA}

A number of scholars have reported that urban food production plays a critical role in two broad ways; (a) addressing the consumptive needs of households [26-28] and (b) supplementing household income or reducing on food expenditure [29-31]. According to Bellwood-Howard et al the most noted benefit of UPA is that it offers households a supply of fresh and nourishing produce and contributes to one fifth to two thirds of the total household food supply [26]. This finding is cemented by Borras Jnr et al who posit that the main function of UPA is seldom for monetary gain but augmenting household consumptive needs [32].

Certainly, there is no shortage of dissenters within discussions on the viability of UPA as a pathway to food security [33-35]. There is a dearth of UA studies that provide statistically grounded evidence of its impact on food security [8]. This has led to wide scepticism among scholars regarding the level of impact UPA has in curbing food insecurity. However, as illuminated by Borras Jnr et al, quantifiable measures of total yields are unattainable because they are seldom captured in 'the official statistics on food production or food circulation' [32]. Using multivariate analysis to assess the food security status of poor city dwellers in northern Bangladesh, Hillbruner and Egan concluded that there was no correlation between engagement in UA and food security [36]. In view of the contentious issue of land in urban areas, there is pessimism surrounding the practice. Using secondary data from a survey conducted by Crush et al in 11 cities in SSA, Frayne et al draw our attention to the overestimated potential of UA among poor households [33,34]. Crush et al's findings highlight that lack of resources among the urban poor means that they derive nominal benefits from UA compared to their more affluent counterparts [33].

\section{Challenges and Constraints of UPA}

Notwithstanding the varying level of benefits UPA engagement offers for households, the activity is plagued by a wide range of constraints. In addition to understanding the significance of UPA, it is vital to identify ways in which cities promote or deter cultivators from drawing maximum benefits from the practice. Moreover, to explore the application of the political concept of food sovereignty in urban food systems, it is important to consider how systems and processes influence the practice. Previous studies have well-articulated the barriers urban farmers face in their agricultural practices, particularly for off-plot cultivation [7,37,38]. Beyond the well-known physical access to land, there are many spectrums to challenges faced by urban cultivators.

Urbanisation as highlighted translates to two related spatial challenges, which are the shrinking of urban spaces due to population growth and the resultant lack of 'readily' available space for food production [1,33]. For example, Crush et al highlight how less than $5 \%$ of poor households in Chipata, Lusaka engaged in UA [33]. This low percentage reflects scarcity of land for food production. Secondly, insecure land tenure is one of the key challenges faced by urban farmers [37,39]. In a pilot project exploring the perception of Indian farmers along the Yamuna River, Cook et al reported how the majority of urban farmers did not have land rights, most either paid rentals or cultivated 'illegally'. They also noted that the ambivalent attitude of government towards UPA discouraged them from making investments in their practices as they could be removed from the land at any time [37]. Correspondingly, Toriro's article which links the growth of UPA in Harare to macro-economic challenges points out that most farmers did not own the land they cultivated [4]. While the designation of vacant spaces to UA in is a rarity, there are cities such as Havana and Dar es Salaam that have reserved spaces specifically for food production [21,39].

One of the key assumptions of the modernisation theory is that tradition is a condition that needs to be remedied by pulling the regressive into 'development.' The production of food is alleged to be illustrative of regression. Sceptics suggest that the practice plays a marginal economic role at the 
city level [40]. By cultivating in cities, urbanites are deemed to be 'ruralising' urban areas. Coined by Stren, ruralisation (Viewed in opposition to modernisation where African cities were planned and arranged resembling 'clean' European cities. Conversely, rural life is associated with backwardness, undeveloped and scattered living arrangements. Therefore, in this context, increasing cultivation of crops and vegetables in cities gravitates towards the concept of the "ruralisation" of urban spaces as coined by Stren (1986)) connotes a degenerative change from the 'developed' city arrangement to the 'undeveloped' [41]. Cultivating in towns, particularly open spaces is counter to growth, planning and development as it spoils the aesthetics of the city. In the American context, Moore describes this reasoning using the concept of the "urban normative", which can be explained as an invented interpretation of a city's structure and function [42]. Urban and peri-urban agriculture is seldom acknowledged through statutes and ordinances. A few states and in some instances cities however have documented and actively work on strategies that enhance household food security through urban food production [43]. Policies and decrees embracing UPA have been put in place in cities such as Accra, Beijing, Brasilia, Bulawayo, Govender Vlders, Havana, Nairobi and Uganda [7,14]. Until 2005, food production in Kampala was unlawful and rendered insubstantial; since its legalisation UPA, its importance has grown. The importance of government mechanisms supporting UPA cannot be overlooked given its primacy in the food provisions of the urban poor [14].

\section{Agroecological or Conventional Practices?}

Literature demonstrates how agroecological principles have been adopted by farmers the world over. Cuba is perhaps the country where the benefits of organic and sustainable growing have been most distinguished [21]. Organic farming involves the harnessing of natural inputs in crop production. It proscribes the use of mechanised implements and synthetic fertilisers and insecticides [44]. The importance of how food is grown is illuminated in Bezner Kerr et al's study on nutrition education [45]. Although Gerster-Bentaya's [43] article on UA focuses on its contribution to food security, the addition of the 'nutrition specific' element sets it apart from other studies. Nutrition-sensitive involves questions ranging from seed acquisition, location of the production, distribution and consumption; all of which are fundamental to principles of the food sovereignty. In a study investigating the motivation behind nutritional change in six countries Nisbett et al provide empirical evidence that gives credence to enhancing food security through localisation [46]. For this reason, the current study focuses on household food security; premised on its direct link to the broader remit of poverty alleviation strategies.

While Nisbett et al focus on the dietary diversity of children, their findings are critical to the argument woven by proponents of agroecology and food sovereignty alike, on the importance of agroecological practices. The study shows how child nutrition improved because of mixed cropping (Two or more crops cultivated concurrently in alternate rows, allowing for agronomic interaction) maize and legumes. [46]. According to Ojiewo et al, legumes not only improve soil fertility through the nitrogen fixation. Intercropping them with crops or vegetables will benefit from the atmospheric nitrogen released from legume roots. Further, planting legumes means that farmers avert spending money on synthetic fertilisers. Nitrogen fixation among other benefits of agroecological practices contribute to the sustainability of the farming systems of household [47].

Scholars have demonstrated $[37,48]$ that small-holder or subsistence farming is not synonymous with agroecological agricultural practice. For example, Mudzengerere's study shows how urban farmers in Bulawayo practised conventional mechanised farming on their farming lots, particularly in low-density areas and peri-urban areas where land was available [48]. For Cook et al, 35 urban farmers engaging in UA along the banks of Yamuna River in Delhi used two to four 50-kilogram bags of fertiliser per 2 ha on average. The largest number of bags used on the same land coverage was six. While organic fertiliser was also used to improve soil quality, less than $33 \%$ of the households applied it to their crops. Of these households, none of them reported the exclusive application of organic fertiliser; it was used as an extra additive to conventional fertiliser. Cook et al attribute the lack of 
sustainable agricultural practices displayed by the Indian farmers to lack of awareness of sustainable alternative practices. They further point out that the insecure tenurial arrangements and minimal involvement by local authorities could be a plausible reason why farmers had limited initiative to capitalise on more sustainable practices [37]. This case study highlights conventional agriculture's power in shaping the perceptions of the Indian farmers.

\section{Creating Edible Landscapes Through Political Analysis}

Globally, a few studies engage in the politics of food provisioning at household level [49], particularly informal agricultural activities. While most studies in the global South have established that the practice of 'illegal' off-plot cultivation is widespread [30,50], they do not move beyond the challenges faced by urban farmers. These studies centre the problem around the vulnerability context, which outlines the effects of external shocks such as financial meltdowns and climatic processes on households. While establishing the impact of such trends on the food (in)security of households is important, such accounts merely describe the experiences of farmers without engaging critical and radical ways in which farmers could propel themselves forward in terms of food provisioning.

Current research that draws into the political dimension of space and validates the view that urban spaces are meant to serve its inhabitants in ways that sustain their existence are largely based in the global North. The writings of Henri Lefebvre feature prominently in agricultural studies related to the politics of space. For example, Shillington (Nicaragua) and Premat (Cuba) explore UA through Lefebvre's Right to the City (RTTC) framework. In Zimbabwe, Mudimu explores strategies urban women use in food production focusing on the politics of space and food security. He demonstrates how the farmers appropriate land that is assessed and earmarked as construction spaces for subsistence agriculture [51]. In defence, respondents reiterated Spivak's 'sanctioned ignorance' [52] concept in positing that municipality administrators reinforced "colonial and male attitudes to city planning" by side-lining UA [51]. In addition to evaluating the various means of land acquisition by urban cultivators in the high density suburb of Kuwadzana, Taru and Basure focus on sources of UA conflict and how cultivators navigate them [53]. While both studies provide valuable insight into the political economy of food, they have a qualitative orientation. Critically, while the conviction displayed by these farmers epitomises the resilience advocated for by proponents of food sovereignty, both studies marginally move beyond the struggles faced by cultivators. Food sovereignty transcends these concerns by accentuating a) the integral nature of the nutritive component of the food produced and b) local knowledge production as it relates to cultivation [54]. The following section expands on the importance of such factors in the food production systems of the urban poor.

\section{Understanding Food Sovereignty}

While no definitional consensus of food sovereignty exists [55] this review borrows La Via Campesina's classical definition; 'The right of peoples to healthy and culturally appropriate food produced through ecologically sound and sustainable methods and their right to define their own food and agriculture systems'. It puts those who produce, distribute and consume food at the heart of food systems and policies rather than the demands of markets and corporations [19]. Coined by peasants' struggles for autonomy in their food systems, food sovereignty is a political concept which advocates shifting from the dominant model of production to one that is more attuned to the needs of the poor [56]. It goes beyond the focus on food security by placing control in the hands of the farmers [54]. Several scholars have demonstrated how applying the food sovereignty approach cushions farmers from market failures and enables them, through sustainable and climate smart agricultural practices, to grow crops that are not only healthy but culturally appropriate for their households [57-59]. Unlike the food security approach, food sovereignty is framed around the wider political context in which farmers exist. For this reason, the proposed study will attempt to assess the feasibility of the FSF in the Zimbabwean context. 
According to La Via Campesina principles embedded in the framework include (1) emphasises the recognition of food as a right (2) values providers by asserting the importance of food production by low income farmers (3) localises the food system by encouraging the food production within communities, (4) places control in local hands by emphasising the sustainable production of food within the surrounds of the community; (5) builds knowledge and skills through sustainable systems and (6) finally works with nature by employing resources and techniques that are sustainable and environmentally friendly [54]. According to Heckelman and Wittman, food sovereignty provides a framework to develop a systems based approach" which focuses on external factors such as power dynamics and the wider ecosystem in which farmers exist [58]. The central argument of this framework is that the control of food systems (from production to consumption) should lie in the hands of the 'cultivators'.

As highlighted earlier, there is a shortage of studies on food sovereignty in Africa. Conversely, peasant driven food sovereignty movements have much wider coverage. Réseau des Organisations Paysannes et de Producteurs de l'Afrique de l'Ouest (ROPPA) in West Africa, Plateforme Sous-Régionale des Organisations Paysannes d'Afrique Centrale (PROPAC) in Central Africa, Eastern and Southern Africa Small scale Farmers Forum (ESAFF) are the most prominent bodies which promote food sovereignty as a pathway to food security [60]. Such movements have catalysed the integration of food sovereignty into state legislation and laws in countries such as Senegal and Mali [61]. In South Africa two key studies [22,62] both situated in KwaZulu-Natal province explore food sovereignty. Noting how food sovereignty remains "invisible" in both policy and practice, Zerbe largely framed using the food security approach, which does not fully engage with issues of power and control [62]. In another study, Ngcoya and Kumarakulasingam explore the lived experience of an elderly woman's' productive practices in the rural village of Mtubatuba. This study provides a good illustration of how her production practices resonate and reflect agroecological practices by using green manure, employing mixed cropping and using invertebrate ecology to enhance soil fertility. What is striking about this example is that she only purchases goods that she cannot produce herself, this attribute resonates with the fourth principle of food sovereignty [22]. Food sovereignty is a tool that facilitates progressive changes to an archaic and restrictive 'urbanism' that is grounded on embracing all social classes and sustainably productive practices [63]. A plethora of studies exist on 'informality' as a key component of the livelihoods of the poor, particularly in relation to food security. Moreover, a few focus directly on sustainable UPA, yet food provisioning is a critical development issue for most African governments.

\section{Weaving Climate Change into Food Sovereignty}

While scientific literature on drivers of climate change have been largely explored, less attention has been paid to its impact on food production [17]. It is therefore important to understand the perceptions of urban cultivators and how they respond to such changes. As highlighted earlier, differential entitlement plays a central role to issues of access to food [5] and relatedly, access to space [64]. Drawing on Sen's analogy, a household's capability to respond to climate variability is also shaped by entitlements.

Adaptation is intrinsically linked to perception. Responding to the third objective of this study, this study highlights the importance of perception. To appreciate local adaptation patterns, it is vital to understand reasoning processes that shape efforts to adapt to climate change [65]. The dearth of empirical evidence on this is tied to the longstanding contention between the science and social science disciplines [66]. Scientists approach the climate change crisis as a problem that is adequately captured through statistical modelling. Recently, however, social scientists have objected to this claim by advocating for the streamlining of traditional knowledge into climate change issues. For example, findings from a study on the perceptions of Cochabamba farmers in Bolivia highlight the vital role of traditional or local ways of knowing in unravelling the intricacies of the climate crisis [65]. In Africa, studies exploring perceptions of farmers on climate change $[67,68]$ have dispelled this by citing 
congruence between the trends observed by farmers and official climate science data. Chiredzi Research station recorded trends which correspond with those elicited from the farmers based in four wards within the Chiredzi district. A mere $10 \%$ of the respondents failed to observe the rise in temperature, evidenced through a rise in "droughts and heat waves" and decrease in rainfall over the past two decades [68].

Using Heckman probit model and a multinomial logit (MNL) analysing adaptation factors among Ethiopian farmers, Gbetibouo's study shows that half of the farmers attuned their practices to the changing weather conditions. Fundamental constraining factors for farmers who failed to adapt were financially related. A logistic regression model of farmer's perception on climate change in southern Ethiopia reflects the same trend reported by Gbetibouo where perception of climate change is high; a) $90 \%$ perceived changes in precipitation (onset, regularity, length, and cessation) and 88.73 in temperature) but adaptation much lower (62.56\%) [67]. Conversely, $84 \%$ farmers in Jiri et al's study adapted to climate change [68]. The study however, focused on agronomic and livestock-based agriculture. Nevertheless, these studies are critical to understanding the importance of local perception in climate science. Extension workers are vital in imparting knowledge on adaptation. Bryan et al's study documents indicate that farmers that erroneously described or failed to distinguish climatic changes had no contact with the 'experts' [69]. There are many channels through which adaption education is distributed. But, for contexts like Zimbabwe, where there is a dearth of Agricultural Extension (Agritex) Officers in rural areas. It would be interesting to understand how a lack of Agritex services affects the adaptive capacities and perceptions of cultivators.

In Zimbabwe, farmers, discernments on climate change and crop production have been dealt with widely [68,70-73]. While they elicit the perceptions of cultivators, they do so from the rural dynamic. In Zimbabwe, studies addressing both caveats; (a) the urban and climate change nexus and (b) the local perceptions of cultivators in climate change are none existent to the author's knowledge. Paradoxically urban dwellers are not immune to climate change and variability. Urban studies focusing on food production and climate change on UPA are few [74]. Motivated by the centrality of curbing the effects of climate variability on food security, this study attempts to address the deficiency of urban views. This is premised on the recognition of heightening the influence of 'the local'.

Horizontal sharing of knowledge is a progressive channel towards food security. Valuing and applying locally constructed considerations of climate change works; (a) to strengthen self-sufficiency among cultivators through integrated knowledge (b) to formulate projects and polices that are context-specific and therefore relevant. For this purpose, drawing on the fifth principle of food sovereignty, the paper advocates for understanding not only the functions of adaptation but more importantly the perception leading to such processes among urban cultivators. By providing input into processes that affect them, cultivators not only shape knowledge but also their food production practices; all of which are pivotal to buttressing food security [59]. Food security and climate change are crises which can be abated through a reduction in activities that increase the formation of GHGs. Food sovereignty, is proffered as one such approach in the field of agriculture.

\section{Food Sovereignty in Zimbabwe}

Food sovereignty's purported significance to self-sufficiency and food security has led some governments to uphold this right through legislation. Ten countries (Argentina, Bolivia, Brazil, Ecuador, El Salvador, Guatemala, Indonesia, Nicaragua, Peru and Venezuela), all of which are found in the global South have ratified food sovereignty into their constitutions [75]. In Africa, a few states such as Mali, Senegal, Ghana, Malawi and South Africa (more so the first two) have begun to embrace the concept of food sovereignty through advocacy [56]. It, however, is still in its embryonic stages. As highlighted earlier, these countries form part of regional networks such as ROPPA, PROPAC and ESAFF. In Zimbabwe, food sovereignty related programmes are gaining traction through the Small Holder Organic Farmers' Forum (ZIMSOFF). A recent report by ZIMSOFF documents the importance of nurturing seed autonomy among small holder farmers through the Zimbabwe Seed Sovereignty 
Programme (ZSSP), which was established in 2014 and advocates for seed autonomy among small holder farmers [76]. While the programme has had reaching effects through its partnership with local non-governmental organisations, the programme's coverage is limited to rural districts. It remains to be seen whether the farmer led movements will initiate processes promoting the integration of food sovereignty into institutional arrangements governing UPA.

As acknowledged in literature, theory does not automatically translate to practice (Carr (1980) comments on the difficulties surrounding the implementation of the spoken or written word.) More so, the ratification of its principles is not a reflection of reality. Cuba, as highlighted above epitomises agroecological food systems, making food sovereignty a relevant concept. An important observation by Beauregard and Gottlieb is that despite the adoption of food sovereignty laws and decrees, Cuba's agricultural performance continues to surpass these and other countries agriculturally [61]. This critique does not intend to moderate the importance of ratification but serves to highlight that identifying food sovereignty requires amalgamating nuances of its principles. More importantly, the coverage of the concept is not as prevalent as the practice. In view of this, this study aims to glean out principles of food sovereignty from the practices of urban households.

In Zimbabwe, Ncube and Ncube divulge the spatial and legislative challenges faced by low-income households in Pumula, Bulawayo [77]. Their work however, does little to engage the agency of households and merely calls for the government to avail more land. This study lacks methodological rigor. While, it employs mixed methods, only one key informant interview was conducted. More key informants would have produced a less biased 'expert' opinion. Two studies [51,53] correspond with food sovereignty's line of enquiry. In exploring the strategies urban women use in food production, Mudimu focuses on the politics of space and food security. He demonstrates how the farmers appropriate land that is assessed and earmarked as construction spaces for subsistence agriculture. In addition to evaluating the various means of land acquisition by urban cultivators in the Kuwadzana high density suburb, Taru and Basure focus on sources of UA conflict and how cultivators navigate them [53]. The studies $[51,53]$ provide valuable insight into the political economy of food; however, they have a qualitative orientation. Critically, while the conviction displayed by these farmers epitomises the resilience advocated for by proponents of food sovereignty, both studies marginally move beyond the struggles faced by cultivators. Food sovereignty transcends these concerns by accentuating (a) the integral nature of the nutritive component of the food produced and (b) local knowledge production as it relates to cultivation [54]. The following section expands on the importance of such factors in the food production systems of the urban poor.

To the author's knowledge no studies based in Zimbabwe drew on any structured research into the opinions and attitudes of farmers on the concept of food sovereignty. This can be attributed to the dominance of the food security approach in both the discipline and practice of agriculture. While a plethora of studies exist on UPA, the majority of these are preoccupied with its merits and demerits $[4,9,78,79]$. Thus, scholarship that explores the relationship between power dynamics and food insecurity are limited. At best, they provide a cursory analysis of the vulnerabilities in the context of challenging environments. While these studies are important in understanding the vulnerabilities of urban households, they are centred on stringent economic crisis conditions and how households respond to them. Also, these studies focus broadly on informal sector activities engaged in by urban dwellers. The current study focuses distinctly on UPA for an in-depth exploration of its role in enhancing the food security status of the urban poor. Beyond the activities of households, it adopts a wider purview by exploring how broader power dynamics affect the 'inventiveness' of urban farmers.

Literature that remotely explores the concept of food sovereignty is relatively thin. Possibly, illuminating the application of food sovereignty among poor urban cultivators' support will reduce household food insecurity. Therefore, there is need to explore this concept in the context of poor households who are increasingly grappling with food provisioning challenges because of worsening economic conditions and the heightened negative effects of climate variability on food production. 


\section{Conclusions}

Considering increasing calls for sustainability due to worsening food insecurity, this study emphasises the need to situate UPA in the wider remit of the production of space and the food sovereignty canon. Access to nutritious and sustainably grown food is borne out by research that shows the merits of espousing food sovereignty. Beyond obtaining food, the concept entails assuming control over one's consumptive needs despite challenges and constraints ranging from policy, socio-economic or socio-political spheres. Literature has outlined the pivotal role UPA plays and more importantly the sustained resilience exhibited by urban cultivators in their quest to curb food insecurity. The practice functions as a tool through which the urban poor evade hunger and poverty, yet institutional arrangements continue to malign the concerns of urban cultivators. Thus, there is need for sustained advocacy from both urban farmers in collaboration with farmer-led movements to anchor policy support that regulates sustainable UPA and designates land for vulnerable urban cultivators. Sustained urbanisation unmatched by economic growth raises the need to not only formalise UPA but engage municipal authorities on the importance of promoting autonomous cultivators through the use of food sovereignty principles. Failure to do so will only fuel hunger and malnutrition in urban spaces in the global South.

Author Contributions: M.C. conceptualized, analysed and prepared the original draft manuscript. P.M. and O.J. provided performed a critical revision of the draft manuscript. M.C. reviewed and edited the final version of the manuscript. All authors approved the final version of the manuscript.

Acknowledgments: We are grateful to the reviewers for their constructive criticism.

Conflicts of Interest: There was no conflict of interest testified by the authors.

\section{References}

1. FAO. Growing Greener Cities in Africa: First Status Report on Urban and Peri-Urban Horticulture in Africa; Food and Agriculture Organization of the United Nations: Rome, Italy, 2012.

2. Pieters, H.; Vandeplas, A.; Guariso, A.; Francken, N.; Sarris, A.; Swinnen, J.; Gerber, N.; von Braun, J.; Torero, M. Perspectives on Relevant Concepts Related to Food and Nutrition Security; LEI Wageningen UR: Wageningen, The Netherlands, 2012.

3. Battersby, J. Urban food insecurity in Cape Town, South Africa: An alternative approach to food access. Dev. Southern Afr. 2011, 28, 545-561. [CrossRef]

4. Toriro, P. The impact of the economic meltdown on urban agriculture in Harare. Urban Agric. Mag. 2009, 21, 26-27.

5. Sen, A. Poverty and Famines: An Essay on Entitlement and Deprivation; Clarendon Press: Oxford, UK, 1981.

6. FAO; IFAD; WFP. The State of Food Insecurity in the World. The Multiple Dimensions of Food Security; Food and Agricultural Organization of the United Nations: Rome, Italy, 2013.

7. Clapp, J.; Cohen, M.J. The Global Food Crisis: Governance Challenges and Opportunities; Wilfrid Laurier University Press: Waterloo, ON, Canada, 2009.

8. Zezza, A.; Tasciotti, L. Urban agriculture, poverty, and food security: Empirical evidence from a sample of developing countries. Food Policy 2010, 35, 265-273. [CrossRef]

9. Pedzisai, E.; Kowe, P.; Matarira, C.H.; Katanha, A.; Rutsvara, R. Enhancing food security and economic welfare through urban agriculture in Zimbabwe. J. Food Secur. 2014, 2, 79-86.

10. FAO. The State of Food Insecurity in the World: Strengthening the Enabling Environment for Food Security and Nutrition; FAO: Rome, Italy, 2014.

11. Hwalla, N.; El Labban, S.; Bahn, R.A. Nutrition security is an integral component of food security. Front. Life Sci. 2016, 9, 167-172. [CrossRef]

12. Jones, A.D.; Ngure, F.M.; Pelto, G.; Young, S.L. What are we assessing when we measure food security? A compendium and review of current metrics. Adv. Nutr. 2013, 4, 481-505. [PubMed]

13. Upton, J.B.; Cissé, J.D.; Barrett, C.B. Food security as resilience: Reconciling definition and measurement. Agric. Econ. 2016, 47 (Suppl. S1), 135-147. [CrossRef] 
14. Cabannes, Y. Pro-Poor Legal and Institutional Frameworks for Urban and Peri-Urban Agriculture; Food and Agriculture Organization of the United Nations: Rome, Italy, 2012.

15. Kimani-Murage, E.W.; Schofield, L.; Wekesah, F.; Mohamed, S.; Mberu, B.; Ettarh, R.; Egondi, T.; Kyobutungi, C.; Ezeh, A. Vulnerability to food insecurity in urban slums: Experiences from Nairobi, Kenya. J. Urban Health 2014, 91, 1098-1113. [CrossRef] [PubMed]

16. Smart, J.; Nel, E.; Binns, T. Economic crisis and food security in Africa: Exploring the significance of urban agriculture in Zambia's Copperbelt province. Geoforum 2015, 65, 37-45. [CrossRef]

17. Sonwa, D.J.; Dieye, A.; El Mzouri, E.H.; Majule, A.; Mugabe, F.T.; Omolo, N.; Wouapi, H.; Obando, J.; Brooks, N. Drivers of climate risk in African agriculture. Clim. Dev. 2017, 9, 383-398. [CrossRef]

18. Pereira, H.M.; Navarro, L.M.; Martins, I.S. Global biodiversity change: The bad, the good, and the unknown. Annu. Rev. Environ. Resour. 2012, 37. [CrossRef]

19. La Via Campesina. Food Sovereignty Now! Unity and Struggle of the People! In Proceedings of the Declaration of Maputo: V International Conference of La Vía Campesina, in Vía Campesina, Maputo, Mozambique, 19-22 October 2008.

20. Boone, K.; Taylor, P.L. Deconstructing homegardens: Food security and sovereignty in northern Nicaragua. Agric. Hum. Values 2016, 33, 239-255. [CrossRef]

21. Premat, A. State power, private plots and the greening of Havana's urban agriculture movement. City Soc. 2009, 21, 28-57. [CrossRef]

22. Ngcoya, M.; Kumarakulasingam, N. The Lived Experience of Food Sovereignty: Gender, Indigenous Crops and Small-Scale Farming in Mtubatuba, South Africa. J. Agrar. Change 2016, 17, 480-496. [CrossRef]

23. Peña, K. Institutionalizing Food Sovereignty in Ecuador. In Proceedings of the International Conference, Food Sovereignty: A Critical Dialogue, New Haven, CT, USA, 14-15 September 2013.

24. Giunta, I. Food sovereignty in Ecuador: The gap between the constitutionalization of the principles and their materialization in the official agri-food strategies. J. Peasant Stud. 2014, 41, 1201-1224. [CrossRef]

25. Yap, C. Urban Food Sovereignty: Food, Land and Democracy in Kampala; Development Planning Unit, Bartlett, University College: London, UK, 2013.

26. Bellwood-Howard, I.; Chimsi, E. Urban and Peri-Urban Agriculture in Tamale: A Policy Narrative; URBANET; UrbanFood Plus; RUAF Foundation; Ghana WASH Programme; University for Development Studies, and International Water Management Institute (IWMI): Colombo, Sri Lanka, 2015.

27. Gallaher, C.M.; Kerr, J.M.; Njenga, M.; Karanja, N.K.; WinklerPrins, A.M. Urban agriculture, social capital, and food security in the Kibera slums of Nairobi, Kenya. Agric. Hum. Values 2013, 30, 389-404. [CrossRef]

28. Rezai, G.; Shamsudin, M.N.; Mohamed, Z. Urban agriculture: A way forward to food and nutrition security in Malaysia. Procedia-Soc. Behav. Sci. 2016, 216, 39-45. [CrossRef]

29. Mougeot, L.J. Urban food production: Evolution, official support and significance. Available online: https: / /idl-bnc-idrc.dspacedirect.org/bitstream/handle/10625/14949/103013.pdf?sequence=1 (accessed on 19 December 2018).

30. Onyango, C.L. Urban-Urban and Peri-Urban Agriculture as A Poverty Alleviation Strategy Among Low Income Households: The Case of Orange Farm, South Johannesburg. Master Thesis, University of South Africa, CapeTown, Johannesburg, South Africa, 2010; p. 230.

31. Tambwe, N.; Rudolph, M.; Greenstein, R. "Instead of begging, I farm to feed my children": Urban agriculture-An alternative to copper and cobalt in Lubumbashi. Afr. J. Int. Afr. Inst. 2011, 81, 391-412. [CrossRef]

32. Borras, S.M., Jr.; Franco, J.C.; Suárez, S.M. Land and food sovereignty. Third World Q. 2015, 36, 600-617. [CrossRef]

33. Crush, J.; Hovorka, A.; Tevera, D. Food security in Southern African cities: The place of urban agriculture. Prog. Dev. Stud. 2011, 11, 285-305. [CrossRef]

34. Frayne, B.; McCordic, C.; Shilomboleni, H. Growing Out of Poverty: Does Urban Agriculture Contribute to Household Food Security in Southern African Cities? In Urban Forum; Springer: Dordrecht, The Netherlands, 2014.

35. Mkwambisi, D.D.; Fraser, E.D.; Dougill, A.J. Urban agriculture and poverty reduction: Evaluating how food production in cities contributes to food security, employment and income in Malawi. J. Int. Dev. 2011, 23, 181-203. [CrossRef]

36. Hillbruner, C.; Egan, R. Seasonality, household food security, and nutritional status in Dinajpur, Bangladesh. Food Nutr. Bull. 2008, 29, 221-231. [CrossRef] 
37. Cook, J.; Oviatt, K.; Main, D.S.; Kaur, H.; Brett, J. Re-conceptualizing urban agriculture: An exploration of farming along the banks of the Yamuna River in Delhi, India. Agric. Hum. Values 2015, 32, 265-279. [CrossRef]

38. Prain, G.; Lee-Smith, D. Urban Agriculture in Africa: What Has Been Learned? In African Urban Harvest; Springer: New York, NY, USA, 2010.

39. De Bon, H.; Parrot, L.; Moustier, P. Sustainable urban agriculture in developing countries. A review. Agron. Sustain. Dev. 2010, 30, 21-32. [CrossRef]

40. Maxwell, D.G. Alternative food security strategy: A household analysis of urban agriculture in Kampala. World Dev. 1995, 23, 1669-1681. [CrossRef]

41. Stren, R.E. The Ruralization of African Cities: Learning to Live with Poverty; Institute for Environmental Studies, University of Toronto: Toronto, ON, Canada, 1986.

42. Moore, S. Forgotten roots of the green city: Subsistence gardening in Columbus, Ohio, 1900-1940. Urban Geogr. 2006, 27, 174-192. [CrossRef]

43. Gerster-Bentaya, M. Nutrition-sensitive urban agriculture. Food Secur. 2013, 5, 723-737. [CrossRef]

44. Reganold, J.P.; Wachter, J.M. Organic agriculture in the twenty-first century. Nat. Plants 2016, 2, 15221. [CrossRef]

45. Bezner-Kerr, R.; Berti, P.R.; Shumba, L. Effects of a participatory agriculture and nutrition education project on child growth in northern Malawi. Public Health Nutr. 2011, 14, 1466-1472. [CrossRef]

46. Nisbett, N.; van den Bold, M.; Gillespie, S.; Menon, P.; Davis, P.; Roopnaraine, T.; Kampman, H.; Kohli, N.; Singh, A.; Warren, A.; et al. Community-level perceptions of drivers of change in nutrition: Evidence from South Asia and sub-Saharan Africa. Glob. Food Secur. 2017, 13, 74-82. [CrossRef]

47. Wezel, A.; Casagrande, M.; Celette, F.; Vian, J.F.; Ferrer, A.; Peigné, J. Agroecological practices for sustainable agriculture. A review. Agron. Sustain. Dev. 2014, 34, 1-20. [CrossRef]

48. Mudzengerere, F.H. The contribution of women to food security and livelihoods through urban agriculture in the city of Bulawayo, Zimbabwe. Zimbabwe J. Sci. Technol. 2012, 7, 1-15.

49. Lombard, M. Constructing ordinary places: Place-making in urban informal settlements in Mexico. Prog. Plan. 2014, 94, 1-53. [CrossRef]

50. Tawodzera, G. Urban household survival and resilience to food insecurity in crisis conditions: The case of Epworth in Harare, Zimbabwe. J. Hunger Environ. Nutr. 2012, 7, 293-320. [CrossRef]

51. Mudimu, G.D. Urban agricultural activities and women's strategies in sustaining family livelihoods in Harare, Zimbabwe. Sing. J. Trop. Geogr. 1997, 17, 179-194. [CrossRef]

52. Spivak, G.C. A Critique of Postcolonial Reason; Harvard University Press: Cambridge, MA, USA, 1999.

53. Taru, J.; Basure, H. Conflicts, contestation and marginalization in urban agriculture: Experiences from Kuwadzana Extension, Harare. Russ. J. Agric. Socio-Econ. Sci. 2013, 18. [CrossRef]

54. La Via Campesina. Nyéléni declaration. Sélingué, Mali: Forum for food sovereignty. In Selingue: Forum for Food Sovereignty. Available online: https://nyeleni.org/spip.php?article228 (accessed on 19 December 2018).

55. Patel, R. Food sovereignty. J. Peasant Stud. 2009, 36, 663-706. [CrossRef]

56. Wittman, H. Food Sovereignty: Reconnecting Food, Nature \& Community; Food First: Oakland, CA, USA, 2010.

57. Carney, M. "Food Security" and "Food Sovereignty": What Frameworks Are Best Suited for Social Equity in Food Systems? J. Agric. Food Syst. Commun. Dev. 2016, 2, 71-87. [CrossRef]

58. Heckelman, A.; Wittman, H. Food Sovereignty: A Framework for Assessing Agrarian Responses to Climate Change in the Philippines. Aust. J. South-East. Asian Stud. 2015, 8, 87-94.

59. Schanbacher, W.D. The Politics of Food: The Global Conflict Between Food Security and Food Sovereignty; ABC-CLIO: Santa Barbara, CA, USA, 2010.

60. Holt Giménez, E.; Shattuck, A. Food crises, food regimes and food movements: Rumblings of reform or tides of transformation? J. Peasant Stud. 2011, 38, 109-144. [CrossRef]

61. Beauregard, S.; Gottlieb, R. Food Policy for People: Incorporating Food Sovereignty Principles into State Governance. Case Studies of Venezuela, Mali, Ecuador, and Bolivia; Urban and Environmental Policy Department, Occidental College: Los Angeles, CA, USA, 2009.

62. Zerbe, N. The Global Politics of Local Food: Community Resistance and Resilience in Durban, South Africa. Unpublished Paper. 
63. Brenner, N.; Marcuse, P.; Mayer, M. (Eds.) Cities for People, Not for Profit: Critical Urban Theory and the Right to the City; Routledge: London, UK; New York, NY, USA, 2012.

64. Lefebvre, H. The Production of Space (1974); Nicholson-Smith, D., Translator; Blackwell: Oxford, UK, 1991; Volume 34, pp. 189-190.

65. Boillat, S.; Berkes, F. Perception and interpretation of climate change among Quechua farmers of Bolivia: Indigenous knowledge as a resource for adaptive capacity. Ecol. Soc. 2013, 18, 21. [CrossRef]

66. Chanza, N.; Mafongoya, P. Indigenous-Based Climate Science from the Zimbabwean Experience: From Impact Identification, Mitigation and Adaptation. In Indigenous Knowledge Systems and Climate Change Management in Africa; Ajayi, O.C., Mafongoya, P.L., Eds.; Technical Centre for Agricultural and Rural Cooperation: Wageningen, The Netherlands, 2017; pp. 67-94.

67. Gbetibouo, G.A. Understanding FARMERS' Perceptions and Adaptations to Climate Change and Variability: The Case of the Limpopo Basin, South Africa; International Food Policy Research Institute: Washington, DC, USA, 2009; Volume 849.

68. Jiri, O.; Mtali-Chafadza, L.; Mafongoya, P.L. Influence of smallholder farmers' perceptions on adaptation strategies to climate change and policy implications in Zimbabwe. Change Adaptation Socio-Ecol. Syst. 2017, 3, 47-55. [CrossRef]

69. Bryan, E.; Ringler, C.; Okoba, B.; Roncoli, C.; Silvestri, S.; Herrero, M. Adapting agriculture to climate change in Kenya: Household strategies and determinants. J. Environ. Manag. 2013, 114, 26-35. [CrossRef] [PubMed]

70. Moyo, M.; Moyo, M.; Mvumi, B.M.; Kunzekweguta, M.; Mazvimavi, K.; Craufurd, P.; Dorward, P. Farmer perceptions on climate change and variability in semi-arid Zimbabwe in relation to climatology evidence. Afr. Crop Sci. J. 2012, 20, 317-335.

71. Mapfumo, P.; Mtambanengwe, F.; Chikowo, R. Building on indigenous knowledge to strengthen the capacity of smallholder farming communities to adapt to climate change and variability in southern Africa. Clim. Dev. 2016, 8, 72-82. [CrossRef]

72. Mtambanengwe, F.; Mapfumo, P.; Chikowo, R.; Chamboko, T. Climate change and variability: Smallholder farming communities in Zimbabwe portray a varied understanding. Afr. Crop Sci. J. 2012, 20, 227-241.

73. Rurinda, J.; Rurinda, J.; Mapfumo, P.; van Wijk, M.T.; Mtambanengwe, F.; Rufino, M.C.; Chikowo, R.; Giller, K.E. Sources of vulnerability to a variable and changing climate among smallholder households in Zimbabwe: A participatory analysis. Clim. Risk Manag. 2014, 3, 65-78. [CrossRef]

74. Tawodzera, G. Urban household vulnerability to food security and climate change: Experiences from urban areas Zimbabwe. In Climate Change, Assets and Food Security in Southern Africa; Earthscan: New York, NY, USA, 2012; Volume 2.

75. Knuth, L.; Vidar, M. Constitutional and Legal Protection of the Right to Food around the World; Food and Agriculture Organization of the United Nations: Rome, Italy, 2011.

76. ZIMSOFF. A Study on Farmer Managed Seed Sysytems (FMSS) in Zimbabwe: Case Studies of Mutoko, Zvishavane and Masvingo. In Farmer Seed Systems (FSS) in Sub-Saharan Africa; ZIMSOFF: Harare, Zimbabwe, 2018; p. 25.

77. Ncube, N.; Ncube, D. Urban agriculture and food security: A case study of Old Pumula suburb of Bulawayo in Zimbabwe. Glob. J. Adv. Res. 2016, 3, 771-782.

78. Mujere, N. The Contribution of Smallholder Irrigated Urban Agriculture Towards Household Food Security in Harare, Zimbabwe. Glob. Urban Agric. 2017, 220.

79. Dube, E. Urban agriculture as a food security strategy for urban dwellers: A case study of Mkoba residents in the city of Gweru, Zimbabwe. PEOPLE Int. J. Soc. Sci. 2017, 3.

(C) 2018 by the authors. Licensee MDPI, Basel, Switzerland. This article is an open access article distributed under the terms and conditions of the Creative Commons Attribution (CC BY) license (http:/ / creativecommons.org/licenses/by/4.0/). 